\title{
Isolasi fungi endofit kulit mentimun (Cucumis sativus L.) dan evaluasi aktivitas penghambatannya terhadap pertumbuhan Candida albicans ATCC 10231
}

\author{
Baru Dwi Yuanwar ${ }^{*}$, Erny Qurotul Ainy ${ }^{2}$ \\ Program Studi Biologi, UIN Sunan Kalijaga Yogyakarta, \\ Jl. Marsda Adisucipto No. 1 Yogyakarta 55281, Indonesia \\ Telp. (0274) 519739 Fax. (0274) 540971 \\ 1dwikhalimah27@gmail.com*; 2erny.ainy@uin-suka.ac.id \\ *korespondensi penulis
}

\begin{abstract}
Abstrak
Mentimun (Cucumis sativus L.) merupakan salah satu tanaman dalam famili Cucurbitaceae yang banyak dibudidayakan. Uji fitokimia ekstrak kulit mentimun menunjukan adanya kandungan senyawa aktif yang berpotensi sebagai antifungi. Fungi endofit mampu memproduksi senyawa aktif yang mirip dengan senyawa yang dihasilkan oleh inangnya. Penelitian ini bertujuan untuk mengisolasi fungi endofit dari kulit mentimun dan menguji aktivitasnya sebagai antifungi terhadap Candida albicans. Fungi endofit diisolasi dari kulit mentimun varietas Baby. Isolat fungi endofit yang telah dipurifikasi kemudian dikarakterisasi secara morfologi dan diuji aktivitas antifunginya dengan metode paper disc assay. Selanjutnya dilakukan uji kualitatif untuk mendeteksi kandungan senyawa aktif antifungi dalam ekstrak isolat fungi endofit. Hasil penelitian menunjukkan bahwa terdapat 5 jenis isolat fungi endofit pada kulit mentimun yaitu AU1, AU2, AT3, BT1, BP2. Identifikasi secara morfologi menunjukkan bahwa isolat AU1 dan BT1 termasuk pada Penicillium, isolat AU2 dan AT3 sebagai anggota genus Cladosporium, dan isolat BP2 teridentifikasi sebagai Aspergillus. Kelima isolat mampu menghambat pertumbuhan Candida albicans. Hasil uji terhadap supernatan masing-masing isolat mengungkap bahwa isolat AU1 dan AT3 terdeteksi memiliki kandungan senyawa flavonoid, isolat BP2 menghasilkan alkaloid dan flavonoid, sedangkan isolat BT1 menghasilkan flavonoid, saponin dan tanin, serta isolat AU2 menghasilkan steroid, flavonoid, saponin dan tanin. Senyawa - senyawa metabolit tersebut berpotensi sebagai antifungi.
\end{abstract}

Kata kunci: Candida albicans, Cucumis sativus L., fungi endofit

\section{Abstract}

Cucumber (Cucumis sativus L.) is one of the plants in the Cucurbitaceae family that is widely cultivated. Phytochemical test of cucumber bark extract shows the presence of active compounds which have potential as antifungal properties. Endophytic fungi are able to produce active compounds that are similar to those produced by their host. This study aims to isolate endophytic fungi from cucumber skin and test its activity as an antifungal against Candida albicans. Endophytic fungi were isolated from Baby cucumber skin varieties. Purified endophytic fungi isolates were then morphologically characterized and antifunctional activity was tested using the paper disc assay method. Furthermore, a qualitative test was conducted to detect the content of antifungal active compounds in endophytic fungi isolate extracts. The results showed that there were 5 types of endophytic fungi isolates on cucumber skin, namely AU1, AU2, AT3, BT1, BP2. Morphological identification showed that AU1 and BT1 isolates included in Penicillium, AU2 and AT3 isolates as members of the genus Cladosporium, 
and BP2 isolates were identified as Aspergillus. The five isolates were able to inhibit the growth of Candida albicans. Test results of the supernatant of each isolate revealed that AU1 and AT3 isolates were detected to contain flavonoid compounds, BP2 isolates produced alkaloids and flavonoids, while BT1 isolates produced flavonoids, saponins and tannins, and AU2 isolates produced steroids, flavonoids, saponins and tannins. These metabolite compounds have the potential to be antifungal.

Keywords: Candida albicans, Cucumis sativus L., endophytic fungi

\section{PENDAHULUAN}

Fungi Candida albicans yang merupakan mikroflora normal pada saluran cerna, urogenital, dan kulit dapat tumbuh dominan dan menyebabkan keadaan patologik kandidiasis yang merupakan infeksi fungi oportunistik, yaitu infeksi fungi sistemik yang terjadi bila ketahanan fagositik host menurun (Mutiawati, 2016). Infeksi $C$. albicans dapat diterapi dengan penggunaan obat antifungi yang efektif untuk pengobatan mikosis, seperti poliena, ß- usitosin, azol, dan griseofulvin. Namun demikian, resistensi patogen terhadap antimikroba sintetik memicu upaya penggalian obat alternatif dari alam yang tidak menimbulkan efek samping (Anggraini \& Masfufatun, 2017), baik dari sumber berupa tumbuhan, hewan, atau mikroba (Prihatiningtias, 2005). Fungi endofit merupakan salah satu sumber senyawa bioaktif yang potensial dikembangkan menjadi obat (Djamaan, 2014). Fungi endofit merupakan mikroba yang hidup di dalam jaringan tumbuhan tanpa menimbulkan gejala penyakit pada inangnya (Radji, 2005)

Menurut Rodriguez et al. (2008), hubungan antara mikroba endofit dan tanaman inang merupakan bentuk simbiosis mutualistic. Fungi endofit yang dapat memproduksi senyawa metabolit sekunder yang mirip dengan yang dihasilkan oleh tanaman inangnya membuka peluang produksi metabolit sekunder untuk antifungi karena jauh lebih efisien dan menguntungkan. Siklus hidup mikroba endofit yang lebih singkat dibanding tumbuhan inangnya dapat menghemat waktu untuk mendapat senyawa metabolit, dan senyawa yang diperoleh dapat dibuat dalam skala besar dengan menggunakan proses fermentasi (Prihatiningtias, 2005).

Mentimun (Cucumis sativus L.) merupakan salah satu tanaman yang banyak dibudidayakan dalam famili Cucurbitaceae (tanaman labu-labuan). Uji kualitatif fitokimia ekstrak kulit mentimun menunjukan adanya kandungan senyawa alkaloid, steroid, flavonoid, saponin dan tanin serta mampu menghambat pertumbuhan mikroba seperti Aspergillus niger, Blastomyces dermatittidis, Candida albicans, Pityrosporum ovale, 
Trichophyton spp, Microsporum spp (Malik \& Akhter, 2012). Namun demikian, penelitian tentang penggunaan fungi endofit dari kulit buah mentimun dalam menghambat pertumbuhan C. albicans belum pernah dilakukan. Oleh karena itu, penelitian ini bertujuan untuk memperoleh isolat fungi endofit dari kulit buah mentimun yang dapat menghambat pertumbuhan C. albicans serta untuk mengetahui kandungan senyawa metabolit sekunder antifungi yang dihasilkannya.

\section{METODE}

\section{Isolasi dan Identifikasi Fungi Endofit}

Sumber isolat fungi endofit berupa buah mentimun varietas Baby umur siap panen yang diperoleh dari Dusun Mblekik, Sardonoharjo, Ngaglik, Sleman. Sampel yang dikumpulkan selanjutnya dimasukkan ke dalam kantong plastik ziplock berukuran $1 \mathrm{~kg}$. Isolasi fungi endofit dilakukan di laminar air flow (LAF) dengan teknik isolasi tidak langsung yaitu dengan menggunakan metode pencucian sampel dan sterilisasi permukaan. Isolasi dilakukan dengan prosedur sebagai berikut: sampel kulit mentimun dicuci di bawah air mengalir selama \pm 10 menit yang dilanjutkan dengan sterilisasi dengan larutan antiseptic secara bertahap yaitu sterilisasi dengan etanol $70 \%$ selama 1 menit, serilisasi dengan larutan $\mathrm{NaOCl} 5,25 \%$ selama 5 menit, dan sterilisasi dengan etanol $70 \%$ selama 0,5 menit. Sampel kemudian dibilas dengan akuades steril. Sampel dipotong kecil kemudian ditumbuk lalu dimasukkan ke dalam akuades steril dengan konsentrasi 10\% (b/v) hingga diperoleh pengenceran $10^{-1}$. Pengenceran dilakukan hingga pengenceran $10^{-5}$ dan kemudian diinokulasikan pada media PDA dengan spread method dan diinkubasi selama 14 hari pada suhu ruang. Isolat ungi endofit yang tumbuh selanjutnya dimurnikan dalam media PDA baru dan diinkubasi kembali selama 14 hari pada suhu ruang. Isolat fungi endofit diamati morfologinya untuk diidentifikasi, baik secara makroskopis yang meliputi warna dan permukaan koloni, tekstur dan arah pertumbuhannya, juga secara mikroskopis yang meliputi tipe hifa dan sporanya.

\section{Fermentasi Isolat Fungi Endofit}

Isolat fungi endofit kemudian digunakan pada tahap fermentasi dengan menggunakan media PDY (Potato Dextrose Yeast). Fermentasi dilakukan dengan cara menginokulasikan fungi endofit berupa potongan miseliumnya yang berdiameter $\pm 1 \mathrm{~cm}$ ke dalam $20 \mathrm{~mL}$ media cair PDY. Kultur diinkubasi pada suhu ruang selama 14 menggunakan rotary 
shaker dengan kecepatan $130 \mathrm{rpm}$. Selanjutnya kultur hasil fermetasi disentrifugasi dengan kecepatan 3000 rpm selama 15 menit, dan supernatannya dipisahkan untuk digunakan pada tahap uji antifungi terhadap C.albicans.

\section{Uji Aktivitas Antifungi Isolat Fungi Endofit terhadap C.albicans}

Uji aktivitas fungi endofit yang berpotensi sebagai antifungi dilakukan dengan metode difusi agar. Kertas cakram steril direndam dalam supernatan isolat fungi endofit kemudian diletakkan pada permukaan media PDA yang sebelumnya telah diinokulasikan dengan C.albicans. Kultur uji diinkubasi pada suhu $35^{\circ} \mathrm{C}$ selama 24 jam dan aktivitas antifungi ditunjukkan dengan zona hambat pada sekeliling cakram. Pada tahap ini digunakan kontrol positif berupa ketokonazol 1\%. Kandungan metabolit sekunder dalam supernatan fungi endofit diidentifikasi secara kualititatif yang meliputi uji alkaloid, steroid, flavonoid, saponin, dan tannin.

\section{HASIL DAN PEMBAHASAN}

Tahap isolasi fungi endofit dari kulit mentimun menghasilkan 5 jenis isolat yang disajikan pada Tabel 1.

Tabel 1. Hasil Isolasi dan Identifikasi Morfologi Fungi Endofit dari Kulit Buah Mentimun Varietas Baby

\begin{tabular}{|c|c|c|c|c|c|c|}
\hline \multirow[t]{2}{*}{ Isolat } & \multicolumn{5}{|c|}{ Karakteristik Koloni } & \multirow{2}{*}{$\begin{array}{l}\text { Taksa Fungi } \\
\text { secara } \\
\text { Morfologi }\end{array}$} \\
\hline & Warna & $\begin{array}{c}\text { Tekstur } \\
\text { Permukaan }\end{array}$ & Tepian & Bentuk & $\begin{array}{c}\text { Arah } \\
\text { pertumbuhan }\end{array}$ & \\
\hline AU1 & $\begin{array}{l}\text { hijau tua } \\
\text { dengan } \\
\text { tepi putih }\end{array}$ & Powdery & $\begin{array}{l}\text { tidak } \\
\text { rata }\end{array}$ & asimetris & radial & Penicillum \\
\hline & $\begin{array}{l}\text { coklat } \\
\text { dengan }\end{array}$ & & & & & Cladosporium \\
\hline AU2 & $\begin{array}{l}\text { bagian } \\
\text { bawah }\end{array}$ & Velvety & rata & asimetris & radial & \\
\hline & $\begin{array}{l}\text { hitam } \\
\text { coklat } \\
\text { dengan }\end{array}$ & & & & & Cladosporium \\
\hline AT3 & $\begin{array}{l}\text { bagian } \\
\text { bawah } \\
\text { hitam }\end{array}$ & Velvety & rata & asimetris & radial & \\
\hline BT1 & $\begin{array}{l}\text { hijau tua } \\
\text { dengan } \\
\text { tepi putih }\end{array}$ & powdery & $\begin{array}{l}\text { tidak } \\
\text { rata }\end{array}$ & asimetris & radial & Penicillium \\
\hline BP2 & warna putih & cottony & rata & asimetris & radial & Aspergillus \\
\hline
\end{tabular}

Hasil isolasi dan identifikasi morfologi fungi endofit dari kulit mentimun (Tabel 1) menunjukkan bahwa dari total 5 isolat fungi endofit terseleksi terdapat 3 genus yaitu Penicillium, Cladosporium, dan Aspergillus. 
Menurut Samson (2016), koloni Penicillium berwarna hijau kusam dengan pola pertumbuhan radial dan berlangsung cepat. Penicillium memiliki konidiofor berbentuk silinder yang bersepta dan bercabang. Bentuk konidianya bulat dan tersusun membentuk untaian seperti rantai serta berwarna abu-abu hijau. Penicillium merupakan salah satu fungi terkenal dan umum ditemukan pada habitat tanah, vegetasi dan berbagai produk makanan. Peran terbesarnya adalah produksi antibiotik penisilin untuk mengobati penyakit infeksi bakterial (Thom, 1945 dalam Visagie et al., 2014). Salah satu fungi yang terkenal dapat menghasilkan penisilin adalah Penicillium chrysogenum (Houbraken et al., 2012 dalam Rachman dkk., 2016).

Gandjar dkk.. (1999) menyebutkan bahwa Cladosporium sp. memiliki penampakan koloni seperti beludru, berwarna hijau tua hingga kecoklatan dengan warna sebalik kehitaman dan tidak memiliki lingkaran konsentris. Konidiofor terbentuk di bagian lateral atau terminal pada hifa, bercabang, berwarna coklat, dapat mempunyai 1 - 3 septum. Konidianya berbentuk elips sampai silindris dengan ujung membulat, berwarna coklat atau coklat kehijauan, dan memiliki bekas tempat duduk konidia. Cladosporium merupakan organisme kosmopolitan yang umumnya ditemukan pada tanaman budidaya sebagai agen penyebab penyakit (Rafal et al., 2012). Beberapa spesies bersifat pathogen terhadap tanaman, diantaranya dapat menyebabkan bintik hitam pada tanaman sereal, keropeng dan bintik - bintik kecoklatan pada daun mentimun, serta bintik-bintik coklat pada daun tanaman tomat (Rafal et al., 2012). Selain itu, menurut Yusuf $d k k$., (2016), genus Cladosporium termasuk salah satu mikoparasit yang potensial dikembangkan sebagai agen hayati pengendali penyakit karat putih pada tanaman krisan dengan salah satu spesies potensialnya adalah Cladosporium cladosporioides.

Menurut (Gandjar dkk., 1999) ciri Aspergillus sp. yaitu koloni umumnya tipis dengan sedikit miselia yang tercampur dengan konidiofor, berwarna putih hingga kuning, struktur koloni seperti kapas. Stipe dari konidiofor berwarna hialin dan berdinding halus, vesikulanya berbentuk bulat hingga semibulat. Konidia berwarna hialin dan berbentuk bulat hingga semibulat. Aspergillus sp. merupakan fungi yang tersebar secara kosmopolitan karena spora funginya mudah disebarkan oleh angin dan mudah tumbuh pada bahan - bahan organik seperti produk pertanian (Praja \& Yudhana, 2017). Aspergillus mampu menghasilkan mikotoksin yang salah satunya adalah aflatoksin yang paling sering dijumpai pada hasil panen pertanian. Aflatoksin adalah salah satu jenis toksin karsinogenik dan hepatotoksik (Mizana $d k k$., 2016). Selain peran 
yang merugikan salah satu spesiesnya, yaitu Aspergillus niger diketahui mampu menghasilkan beberapa jenis enzim seperti $\alpha$-amilase, selulase, laktase, pektinase, protease, infertase, dan amiloglukosidase. Selain enzim, fungi ini juga dapat memproduksi asam organik seperti asam sitrat dan asam glukonat (UI Haq, et al., 2003).

Proses fermentasi fungi endofit dilakukan dengan menggunakan media cair karena pada media ini produksi biomassa dan senyawa bioaktif lebih efektif dibamdingkan dengan fermentasi menggunakan media padat. Dalam fermentasi cair diberikan agitasi yang memungkinkan nutrisi dalam media dapat terus homogen sehingga mikrobia dapat lebih optimal mengabsorbsi nutrisi tersebut (Nurhidayah $d k k$., 2014). Agitasi bertujuan untuk meningkatkan suplai oksigen dalam medium dan meningkatkan pertukaran panas sehingga distribusi suhu menjadi homogen di seluruh bagian substrat (Kumala \& Pratiwi, 2014), sehingga diperoleh ekstrak dengan konsentrasi yang sama..

Ekstrak dari lima isolat fungi endofit kulit mentimun diuji kemampuannya dalam menghambat pertumbuhan $C$. albicans dan hasilnya ditunjukan pada Tabel 2.

Tabel 2. Uji Aktivitas Antifungi terhadap C. albicans oleh Isolat Fungi Endofit Kulit Mentimun

\begin{tabular}{ccc}
\hline $\begin{array}{c}\text { Isolat Fungi } \\
\text { Endofit }\end{array}$ & $\begin{array}{c}\text { Rata - rata } \\
\text { Diameter Zona } \\
\text { Hambat }(\mathbf{m m})\end{array}$ & $\begin{array}{c}\text { Kategori Antifungi (Davis \& Stout, 1971 } \\
\text { dalam }\end{array}$ \\
\hline Kontrol & 13,2 & Kuariaman, 2016) \\
AU1 & 3,4 & Lemah \\
AU2 & 3 & Lemah \\
AT3 & 1 & Lemah \\
BT1 & 2 & Lemah \\
BP2 & 9,7 & Sedang \\
\hline
\end{tabular}

Hasil uji aktifitas antifungi pada Tabel 2 menunjukkan bahwa semua isolat fungi endofit mampu membentuk zona bening yang mengindikasikan adanya aktivitas antifungi isolat terhadap C. albicans dengan zona hambat terbesar sebesar 9,7 $\mathrm{mm}$ dihasilkan oleh isolat BP2 (Aspergillus). Namun demikian, ukuran zona hambat yang terbentuk oleh masing-masing isolat lebih rendah dibandingkan zona hambat yang terbentuk pada kontrol positif. Ketokonazol dipilih sebagai kontrol positif karena merupakan golongan azol yang lebih baik dalam menghambat pertumbuhan $C$. albicans dibandingkan golongan antifungi yang lain (Hamdanah, 2012). Dengan demikian diketahui bahwa daya hambat metabolit sekunder dari isolat fungi endofit kulit mentimun terhadap pertumbuhan Candida lebih kecil dibandingkan dengan ketokonazol. 
Isolat BP2 menunjukkan kemampuan menghambat $C$. albicans paling baik dengan hasil karakterisasi menunjukkan kemiripan dengan Aspergillus sp. Menurut Elfina $d k k$., (2013), Aspergillus sp. memiliki kemampuan menghambat fungi dikarenakan metabolit sekunder aktif yang dihasilkannya. Singh dan Bharate (2005), secara umum senyawa antimikroba yang dihasilkan oleh Aspergillus sp. bersifat netral, polar dan memiliki gugus fenol. Fenol mampu mendenaturasi protein pada dinding dan membran sel fungi. Xue et al., (2012), menyebutkan senyawa metabolit pada Aspergillus sp. diantaranya adalah senyawa terpen dan alkaloid.

Fungi endofit yang dihasilkan oleh tumbuhan inang dapat menghasilkan jenis isolat yang berbeda - beda dengan jumlah bervariasi. Wahyudi (2001) juga mengatakan bahwa isolasi fungi endofit dari bagian tanaman yang berbeda dari satu tumbuhan inang menghasilkan jenis isolat yang berbeda. Bahkan dari satu jaringan hidup suatu tumbuhan dapat diisolasi lebih dari satu jenis fungi endofit. Hal ini merupakan implikasi dari mekanisme adaptasi dari endofit terhadap mikroekologi dan kondisi fisiologis yang spesifik dari masing-masing tumbuhan inang.

Kemampuan isolat fungi endofit dalam menghambat pertumbuhan C. albicans disebabkan aktivitas senyawa metabolit sekunder yang dimilikinya. Hasil uji senyawa metabolit sekunder dari supernatan setiap isolat fungi endofit kulit mentimun ditunjukkan pada Tabel 3.

Tabel 3. Senyawa Metabolit Sekunder yang Dihasilkan oleh Fungi Endofit Kulit Mentimun

\begin{tabular}{cccccc}
\hline \multirow{2}{*}{ Senyawa Metabolit Sekunder } & \multicolumn{5}{c}{ Isolat Fungi Endofit } \\
\cline { 2 - 6 } & AU1 & AU2 & AT3 & BT1 & BP2 \\
\cline { 2 - 6 } Alkaloid & - & - & - & - & + \\
Steroid & - & + & - & - & - \\
Flavonoid & + & + & + & + & + \\
Saponin & - & + & - & + & - \\
Tanin & - & + & - & + & - \\
\hline
\end{tabular}

Keterangan:

(-): hasil uji negatif

(+): hasil uji positif

Kemampuan fungi endofit yang rendah dalam menghambat fungi lain diduga disebabkan oleh konsentrasi senyawa yang dihasilkan isolat fungi rendah. Hal ini sesuai dengan pernyataan Pelczar \& Chan (1988), bahwa semakin tinggi konsentrasi zat antifungi maka semakin tinggi daya antifunginya yang terepresentasikan dalam ukuran zona hambat. Perbedaan ukuran diameter zona hambat selain disebabkan oleh konsentrasi zat bioaktif, dapat juga disebabkan oleh zat yang dihasilkan oleh masing - 
masing isolat juga berbeda. Hal ini sesuai dengan yang diungkapkan oleh Wallhausser (1995) dalam Nurhidayah $d k k$., (2014) bahwa antibiotik mempunyai spesifikasi dalam efektifitasnya.

Antibiotik merupakan zat kimia yang dihasilkan oleh suatu mikroorganisme yang mempunyai kemampuan dalam menghambat pertumbuhan mikroorganisme lain (Pelczar \& Chan, 1988). Menurut Purwanto (2000), antibiotik yang dihasilkan mikroorganisme endofit berupa metabolit sekunder. Masing - masing senyawa metabolit sekunder memiliki cara kerja yang berbeda - beda (Fitriani et al., 2012). Alkaloid diketahui dapat menyebabkan membran sel bocor; flavonoid dapat melisiskan membran sel; steroid mampu menghambat sintesis kitin dan saponin menghambat sintesis dinding sel, melisiskan sel fungi dan menghambat pertumbuhan; serta senyawa tanin dapat menghambat enzim glikosiltransferase yang berperan dalam sintesis kitin. Isolat BP2 menunjukkan kemampuan terbaik dalam menghambat $C$. albicans serta diketahui memiliki kemiripan dengan Aspergillus sp., dimana Aspergillus sp. memiliki kemampuan menghambat fungi karena metabolit aktif yang dihasilkannya berupa senyawa polar dengan gugus fenol dan senyawa alkaloid.

Menurut Pratiwi (2008), senyawa yang bersifat sebagai antimikroba adalah alkaloid, saponin, flavonoid, senyawa fenolik hidrokuinon dan tanin. Subhisha (2005) menyatakan bahwa steroid juga berfungsi sebagai antifungi. Dengan demikian, isolat fungi endofit dari kulit buah mentimun menghasilkan alkaloid, steroid, flavonoid, saponin dan tanin yang dapat berperan sebagai antifungi yang menghambat pertumbuhan C. albicans.

\section{SIMPULAN}

Diperoleh lima isolat fungi endofit dari kulit buah mentimun yaitu, AU1, AU2, AT3, BT1 \& BP 2. Identifikasi secara morfologis menunjukkan bahwa isolat AU1 dan BT1 termasuk pada Penicillium, isolat AU2 dan AT3 mirip dengan Cladosporium, serta isolat BP2 termasuk Aspergillus. Kelima isolat mampu menghambat pertumbuhan C. albicans. Ekstrak isolat AU1 dan AT3 mengandung flavonoid, isolat BP2 mengandung alkaloid dan flavonoid, isolat BT1 berupa flavonoid, saponin dan tanin, sedangkan isolate AU2 mengandung steroid, flavonoid, saponin dan tanin. Masing-masing metabolit sekunder tersebut memiliki aktivitas sebagai antifungi. 


\section{REFERENSI}

Anggraini, V. \& Masfufatun, M. (2017). Efektivitas Kombinasi Ekstrak Daun Sirih Merah (Piper crocatum) dan Ekstrak Biji Alpukat (Persea americana) dalam Menghambat Pertumbuhan Candida albicans. Jurnal Kimia Riset, 2(2): 86 - 92.

Djamaan, A., Asia \& Wahyuni, R. (2014). Isolasi Mikroba Endofit dari Kulit Batang, Daun, dan Kulit Buah Manggis (Garcinia mangostana L.) Pengkulturan serta Uji Aktivitas Antimikrobanya. Jurnal Farmasi Higea, 6(1): 90-97.

Elfina, D., Martina, A. \& Roza, R. M. (2013). Isolasi dan Karakterisasi Fungi Endofit dari Kulit Buah Manggis (Garcinia mangostana L.) sebagai antimikroba terhadap Candida albicans, Staphylococcus aureus dan Escherichia coli. Pekanbaru: FMIPA Binawidjaya.

Fitriani, A., et al. (2012). Aktivitas Antifungi Ekstrak Etanol Daun Salam (Syzygium polyanthum (Wight) Walp.) terhadap Pertumbuhan Jamur Candida albicanssecara in vitro. Biosfera 29 (2): 71-79

Gandjar, I., Samson, A. Robet., Tweel-Vermeulen, K., Oetari, A., Santoso, I., (1999). Pengenalan Kapang Tropik Umum. Jakarta: Yayasan Obor Indonesia.

Hamdanah. (2012). Keragaman Kepekaan C. albicans yang Diisolasi dari Lokasi Peternakan Sapi Perah terhadap Beberapa Anticendawan. [Skripsi]. Bogor: IPB.

Kumala, S \& Pratiwi, A. A. (2014). Efek Antimikroba dari Kapang Endofit Ranting Tanaman Biduri. Jurnal Farmasi Indonesia, 7(2): 111-120.

Malik, J. \& Akhter, R. (2012). Phytochemical Screening and In-vitro Evaluation of Reducing Power, Cytotoxicity and Anti-Fungal Activities of Ethanol Extracts of Cucumis sativus. International Journal of Pharmaceutical \& Biological Archives, 3(3): 555-560.

Mizana, D. K., Suharti, N. \& Amir, A. (2016). Identifikasi Pertumbuhan Fungi Aspergillus sp. pada Roti Tawar yang Dijual di Kota Padang Berdasarkan Suhu dan Lama Penyimpanan. Jurnal Kesehatan Andalas, 5(2): 355-360.

Mutiawati, V. K. (2016). Pemeriksaan Mikrobiologi pada Candida albicans. Jurnal Kedokteran Syiah Kuala, 16: 53-63.

Nurhidayah., Hasanah, U. \& Idramsa. (2014). Pengaruh Ekstrak Metabolit Sekunder Fungi Endofit Tumbuhan Cotylelobium melanoxylon dalam Menghambat Pertumbuhan Mikroba Patogen. Medan: Universitas Negeri Medan,

Pelczar, M. J. \& Chan, E. C. S. (2005). Dasar-Dasar Mikrobiologi. Jakarta: Universita Indonesia Press.

Praja, R. N. \& Yudhana, A. (2017). Isolasi dan Identifikasi Aspergillus spp. pada ParuParu Ayam Kampung yang Dijual di Pasar Banyuwangi. Jurnal Medik Veteriner, 1 (1): 6-11.

Pratiwi. (2008). Mikrobiologi Farmasi. Jakarta: Erlangga

Prihatiningtias, W. (2005). Senyawa bioaktif Fungi Endofit Akar Kuning (Fibraurea chloroleuca Miers) sebagai senyawa antimikroba. [Thesis]. Yogyakarta: Sekolah Pascasarjana UGM.

Purwanto, R. 2008. Peranan Mikroorganisme Endofit sebagai Penghasil Antibiotik. www.kabarindonesia.com. Diakses Februari 2019 
Rachman, S. D., Safari, A., Fazli., Kamara, D. S., Siddik, A. \& Udin, L. Z. (2016). Produksi Penisilin oleh Penicillium chrysogenum L112 dengan Variasi Kecepatan Agitasi pada Fermentor 1 L. Jurnal Ilmiah Farmasi, 4(2): 1-6.

Radji, M. (2005). Peranan Bioteknologi dan Mikroba Endofit dalam Pengembangan Obat Herbal. Majalah Ilmu Kefarmasian, 2(3): 113-126

Rafal., Lejman, A., Pusz, W., Miluch, A. \& Miodynska, P. (2012). Characteristics and Taxonomy of Cladosporium Fungi. Mikologia Lekarska, 19(2): 80-85.

Rodriguez, R. J., White, J. F., Arnold., A. E. \& Redman, R. S. (2009). Fungal Endophytes: Diversity and Functional Roles. NewPhytologist, 182: 314- 330.

Samson, A. R. (2016). Training Course for The Identification of Aspergillus, Penicillium and Talaromyces. Netherlands: Westerdijk Fungal Biodiversity Institut, Utrecht.

Singh, I. P. \& Bharate, S. B. (2005). Anti-HIV Natural Products. Journal Current Science, 89: $269-290$.

Subhisha, S. (2005). Antifungal Activities of a Steroid from Pallavicinia lyllii a Liverwort. Tropical Botanic Garden and Research Institute.

UI Haq, I. S., Ali, M. A. Qadeer \& Iqbal, J. (2003). Control of Asppergillus niger Morphology to Enhance Citric Acid Production Under Liquid Culture. Pakistan Journal Botany, 35(4): 533-539.

Visagie, C. M., Houbraken, J., Frisvad, J. C., Hong, S. B., Klaassen, C. H. W., Perrone, G., Seifert, K. A., Varga, J., Yaguchi, T. \& Samson, R. A. (2014). Identification and Nomenclature of the Genus Penicillium. Studies in Mycology, 78: 343-371.

Wahyudi, P. (2001). Mikroba Endofitik: Simbion dalam Jaringan Tanaman. Lingkungan Manajemen Ilmiah. 3 (2): 45-50

Xue, H., Lu, C., Liang, L. \& Shen, Y. (2012). Secondary Metabolites of Aspergillus sp. CM9a, an Endophytic Fungus of Cephalotaxus manni. Natural Product, 6 (10): 2834.

Yusuf, E. S., Nuryani, W. \& Hanudin. (2016). Isolasi dan Identifikasi Mikoparasit Utama pada Karat Krisan. Jurnal Hortikultura. 26(2): 217-222. 